\title{
Funding review set to buck up basic research
}

\section{Jim Giles, London}

British scientists are looking forward to a spending announcement that could set the scene for a major revival in their fortunes over the next decade.

Britain's chancellor of the exchequer Gordon Brown is expected to announce plans to almost double spending on scientific grants and infrastructure over the next ten years, as part of a general spending review, which is provisionally scheduled to be released on 24 June.

The review is likely to favour established areas of priority, including clinical studies and spending on climate-change research. "There are bound to be winners and losers," notes Ian Gibson, Labour member of parliament for Norwich North and chair of the House of Commons science and technology select committee.

A report in The Times Higher Education Supplement on 11 June said that the plan would increase spending on the research councils, which fund most basic research grants in Britain, by 5.7\% a year for ten years. A senior official close to the process says this is "not out of line" with what the final review will contain.

The official added that the review will emphasize basic scientific research, which the Labour government believes to be an important competitive advantage for Britain.

The plan will also make special provision for the support of interdisciplinary research, the official said, and could lay the ground-

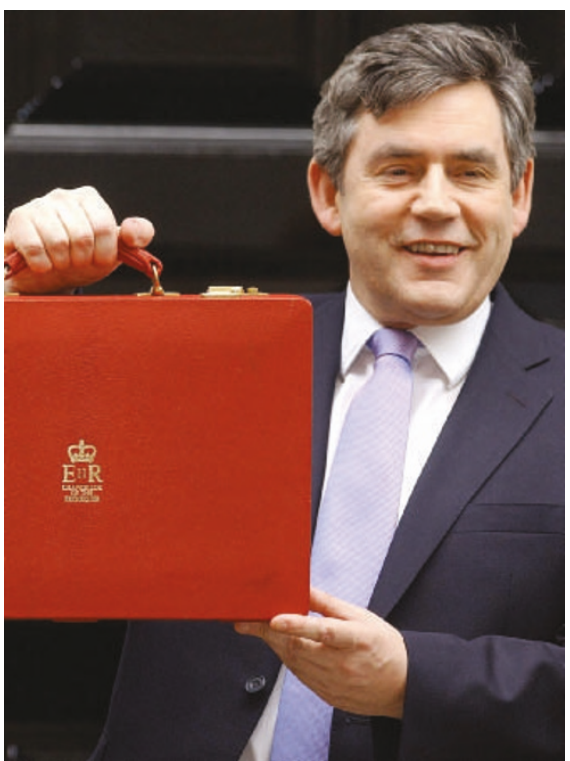

Best case scenario: Gordon Brown's plan could double spending on science over the next ten years.

work for scientists and engineers at British universities to supplement their salaries through research income, as is possible in the United States. Inequalities in academic salaries are seen as a significant contributor to the brain drain of British scientists across the Atlantic.

Brown's plan was warmly welcomed by Peter Cotgreave, director of Save British Science, a lobby group formed at the height of that brain drain in the early 1980s. "It's great that they are addressing the issues we have been highlighting," he says.

The Labour government has already increased the budget of the research councils by $£ 1$ billion ( $\$ 1.8$ billion) to $£ 2.2$ billion since it came to power in 1997. But Cotgreave says that researchers continue to struggle to win grant funding, partly because so much of the investment has gone on infrastructure. "There is still no better chance of getting basic research funded," he says.

If it is implemented, next week's plan could change that. But the money is unlikely to be spread evenly between the seven research councils; medical and environmental research are likely to fare best.

A special fund for interdisciplinary projects is expected to be formed under the strategy and to be administered by Keith O'Nions, an earth scientist who became director-general of the research councils in January.

The question of academic salaries is also set to be addressed in next week's announcement. The government is thought to be considering a scheme that would allow university researchers to receive their current annual salaries from universities for nine months' work and to earn supplemental income from research grants during the rest of the year. But the success of such a scheme would depend on the willingness of independent grant-funding bodies, such as the Wellcome Trust, to support salaries as well as research.

\section{Fresh study questions oldest traces of life in Akilia rock}

\section{Rex Dalton, San Diego}

A famous study that found hints of the earliest life on Earth in Greenland rock has been thrown into doubt after researchers failed to replicate the work.

The quartzite rock, which comes from Akilia Island, was reported to contain organic carbon in crystals of a bone-like material called apatite - a promising sign of life (S. J. Mojzsis et al. Nature 384, 55-59; 1996). The rock was dated at about 3.85 billion years old, millions of years older than other signs of life found in Greenland and hundreds of millions of years older than evidence of life elsewhere.

The findings have been disputed before. Some researchers say the carbon cannot be proven to have a biological origin (C. M. Fedo and M. J. Whitehouse Science 296, 1448-1452; 2002). Others have suggested that the rock is not as old as originally thought (Y. Sano et al. Nature 400, 127; 1999).

There is now a fresh challenge. On

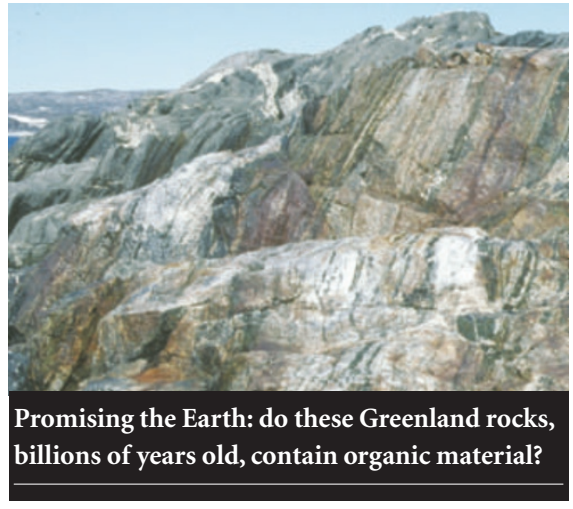

11 June at a Goldschmidt Geochemistry conference in Copenhagen, Denmark, Aivo Lepland told scientists that he could not replicate the original study. Lepland, now with the Geological Survey of Norway, Trondheim, and his colleagues spent five years examining 15 different rock samples from the same outcrop in Akilia, but found no organic carbon in apatite crystals.
"I think there must have been a mix-up of samples," says Gustaf Arrhenius, a geochemist at the Scripps Institution of Oceanography in La Jolla, California, who is the senior author on both the original report and the recent presentation. Arrhenius says a sample from Greenland's nearby Isua formation, where there are organic carbon crystals in younger rock, may have inadvertently been attributed to Akilia. The original study may also have hit upon a genuine but rare find.

The original Akilia rock analysis was performed by Steven Mojzsis, then Arrhenius's doctoral student and now a geochemist at the University of Colorado in Boulder. Mojzsis, who attended the conference, told Nature he doubted there was a mix-up of samples, but he declined to discuss the specifics of Lepland's work. He and Lepland have agreed to divide the original samples for more analysis and have gone to examine Akilia and other sites in Greenland this week. 